\title{
Transport of delight
}

\author{
The highs and lows of commuting.
}

\section{Roland Denison}

The cyclist flies downhill towards the city in a semi-trance of endorphins and adrenaline. Trafficlights change a fraction before he would have reached for the brakes as he shoots pasthospital, shops and park. From here the road runs flat and straight, aimed at the heart of the old city. He slips his derailleur down and rises from the saddle to maintain speed. A week ago he couldn't have done that. Even yesterday he would have been navigating a fractured route between the bumpers of stationary vehicles; an inconstant path whose gaps and alleys closed and opened without warning.

But today is special. Today there is no traffic. The roads belong to him alone.

Moving the citizenry around had never been simple. Centuries before, carts had been forbidden entry to the city during the hours of daylight. The bridges over the river, whose oily tang he can already smell, bore toll-gates. In the current century that idea was reinvented. Batteries of camerasstanding guard, noting down entries in their electronic ledgers and tallying up their fee. Soon every road in the metropolitan area, indeed the whole country, had its own tariff. To keep track of this revenue, vehicles were fitted with radio tags to pinpoint their position

to within half a metre. And still the jams worsened, average speeds dropped, and drivers seethed.

The cyclist raises his cadence for his favourite part of the journey: two interlinked gyratories, once the boundary of the original levy. Slowing slightly, he leans into the initial left-hand bend, right foot down to avoid clipping the tarmac. Then to the right, straightens for eight cranks to maintain momentum for the second left-right-left combination. Ten seconds of bliss that any bobsleigh pilot would envy.

Half a mile on, a cluster of side streets form the shortest path to the river. Here the presence of pavements makes corners difficult to judge. He can just remember when all roads in the city had pedestrianthronged sidewalks, but their users were

long since driven away by the dangers of the adjacent road. Then the roads were widened to engulf the redundant walkways. But, as so often before, larger roads encouraged more traffic and greater congestion.

Drivers had felt discriminated against by the tagging and tolls, their human rights infringed. The judiciary agreed, but rather than abolish the offence, the government abolished the discrimination, extending it to the entire populace. Personal identity cards became subcutaneous identichips. An

entire popula-

tion located

to within

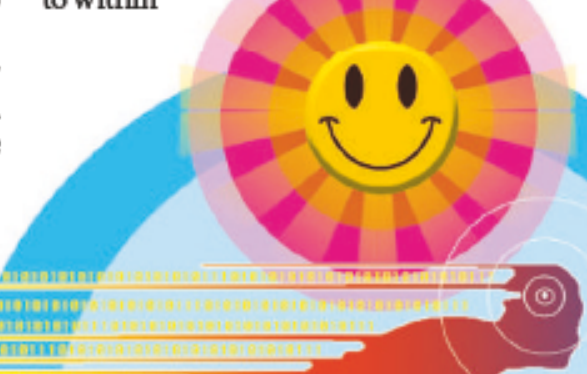

have, if they dare try, a glorious life." He has read this every day for years but it was only last week that he had grasped its meaning. Yet a glorious life seemed too ambitious: but a glorious day, he could dare that much.

The CTC had long since calculated a solution to the city's traffic woes. Traffic created congestion, vehicles created traffic - banish the vehicles, abolish the jams. But that wasn't politically acceptable. Instead, the data logs on which the CTC based its calculations had to be amended. A lie of omission to keep the CTC labouring in the vain hope that the traffic could be made to flow. That was the cyclist's job.

Standing on the pedals he ascends the bridge crossing the wide river in glorious isolation before plunging between the artificial cliffs on the north bank. Past theatres, banks, museums, bars and shops, his progress continuous and unimpeded. Today the streets are his - for yesterday he had dared the truth. He had passed the logs unexpurgated to the CTC and it had drawn its inevitable conclusion.

He nears his office overlooking the canal,

a previous century's attempt at traffic management. He dismounts on the move, jogging a few steps to bring the bicycle to a stop.

Under the influence of the enlightened CTC, the periphery of the city is currently populated with artificially contented dri-

20 centimetres, day and night.

All the information was processed by a central traffic computer, the CTC, which the cyclist was paid to deceive. At first it simply advised in-vehicle navigation systems, but that had little effect. Everyone had a better idea on how to beat the jams. Everyone knew a secret shortcut. No one followed its advice. The G5 riots changed that. Hastily passed legislation upgraded citizens' identichips to release endorphins and their antagonists under remote control. Now the CTC could make drivers feel good about following its route planning and depressed for ignoring it, but even so the traffic didn't move.

The cyclist passes a motto, written on the side of a 300-year-old church: "All may vers travelling in futile circles. Today the city streets are the cyclist's domain, and it feels good.

As he reaches the door the euphoria that has carried him through his journey evaporates, replaced by a weight of dread. He turns, remounts his bike and cycles back into the city, his moodlifting immediately with a fresh endorphin release.

Today he belongs to the roads and their call cannot be denied.

Roland Denison has recently left the XVth Directorate of the European Commission for the Wageningen offices of the United Nations. His novels featuring the alternativerealities private detective Giles Coppice continue to attract a cult following. 